\title{
WHITE FARMERS' DEALINGS WITH LAND REFORM IN SOUTH AFRICA: EVIDENCE FROM NORTHERN LIMPOPO PROVINCE
}

\begin{abstract}
Completing restitution, a key element of South Africa's land reform programme, entails government acquisition of white-owned farms. Some white farmers are willing to sell and consequently the government has paid them full market-related compensation. Others, however, refuse to sell, a right they have under the terms of the willing-seller, willing-buyer principle to which the government has committed itself. Why white farmers refuse to sell, even when compensation is on offer, is poorly understood. This paper therefore draws on qualitative research concerning white farmers in the Levubu area of northern Limpopo province to fill this gap in knowledge. The paper asks why white farmers were refusing to sell land to make way for restitution. It interrogates the material and symbolic factors affecting farmers' action and demonstrates that the respondents' justified their stance in relation to shifts in power in the agricultural sector, developments in land reform practice, and the respondents' strong emotional bond to the land. In so doing, the paper calls into question the underlying (materialist) logic of the government's mode of land acquisition.
\end{abstract}

Key words: Land restitution; South Africa; semi-structured interviews; willingseller, willing-buyer; White farmers; Limpopo province; Levubu. 


\section{WHITE FARMERS' DEALINGS WITH LAND REFORM IN SOUTH AFRICA: EVIDENCE FROM NORTHERN LIMPOPO PROVINCE}

\section{INTRODUCTION}

A central concern of South Africa's post-1994 democratic governments has been to alter the country's racially skewed distribution of land (Levin \& Weiner 1997). A land reform programme therefore exists to redistribute thirty percent of agricultural land from the country's approximately 45000 white farmers. One of the most pressing elements of land reform is restitution, a programme which enables groups of people dispossessed of rights in land under the terms of racially discriminatory laws enacted since the 1913 Natives’ Land Act to claim back their land (for excellent reviews of restitution, see Hall 2003, 2004). A key aim of restitution is to provide redress to those dispossessed of land prior to the apartheid era beginning in 1948 as well as those (or their descendants) among the 3.5 million people who were forcibly moved from 'black spots' in the so-called 'white countryside' into the apartheid-era reserves or 'Homelands' between 1960 and 1985 (Platzky \& Walker 1985). ${ }^{i}$ Valid claims for restitution for these injustices are compensated by transfers of land or other means, including cash payments. However, recent estimates suggest that only around $6 \%$ of settled rural restitution claims have involved land transfers (Umhlaba 
Wethu 2005). The remaining claims, though, are mostly rural and expectations are that they will involve land transfers.

Whilst completing restitution entails the government buying particular tracts of land from them or other landowners and then transferring the land to beneficiaries, the South African government has been restricted in how it can acquire land. According to the terms of a 'willing-seller, willing-buyer' principle to which it has committed itself, the government must offer marketrelated compensation to landowners. Moreover, landowners can sell to other buyers besides the government. Farmers, then, have discretionary power, tantamount to a veto, to decide whether to sell to the government (Lahiff 2005). The fact that the government committed itself to this restricted mode of acquisition reflects the experience of land reform elsewhere in Southern Africa, as Lahiff (2005) has noted, as well as the government's broader commitment in the Interim and final Constitutions to protect private property rights (Ntsebeza 2006). But the stance on land acquisition also has strong associations with the Market-Led Agrarian Reform (MLAR) thesis advanced particularly by World Bank economists Deininger and Binswanger (Deininger and Binswanger 1999; Ghimire 2001; Borras 2005). Under MLAR principles, land reform is intended to be a negotiated and de-politicized process in which landowners come forward to sell when offered market-rated prices for their land. An underlying assumption of MLAR and a critical aspect of the logic underpinning the mode of land acquisition adopted by the South African government, is that 
landowners are motivated by material interests. Such an assumption might seem reasonable given the World Bank's perspective; economic interests trump all others, in its view. However, experience of land reform in South Africa has already indicated that landowners are not motivated by economic interests alone. ${ }^{\text {ii }}$ In particular, while some white farmers have agreed to sell their land and either move onto another of their properties or shift their investments into other economic sectors; many others obstinately refuse to sell. These latter farmers have market-rated compensation on offer but have not come forward to sell.

It is of fundamental importance to note here that large numbers of white farmers refusing to sell is not necessarily a problem for the government's redistribution programmes because, besides those refusing to sell, sufficient numbers of sellers may still come forward. Restitution, though, is a different matter altogether: expropriation eventually will be the government's only option of acquiring land if insufficient numbers of white farmers agree to sell land. One high-ranking government official involved in the Limpopo restitution process said, "we will declare disputes with [those who refuse to sell] and we will expropriate. [There is] No other route. We will expropriate” (Personal Interview with Official from Limpopo Land Claims Commission, September 2004). Yet, such comments by provincial officials notwithstanding, the government is "greatly reluctant" (Ntsebeza 2006 p.123) to take this route, not least, it would seem, because expropriation risks parallels being drawn between 
South Africa's land reform process and the controversial 'fast-track' (Bernstein 2002) process of land reform in Zimbabwe. Consider here how conservative media raise alarm bells when South African government officials discuss expropriation: “'Zimbabwe' land option mooted by SA officials” (Business Day, October 16 2006; my emphasis). The situation with respect to restitution, therefore, prompts questions about why white farmers refuse to sell. It raises questions about the extent to which the logic underpinning the MLAR thesis on modes of land acquisition is suited to the task of delivering land for land reform. Are white farmers motivated by material interests alone; is the government's willing-seller, willing-buyer principle likely to deliver sufficient numbers of sellers?

In this general context, I argue in this paper that the case of white farmers in South Africa calls attention to the difficult task of determining whether material interests trump other interests of a more symbolic sort (and vice versa). One way to navigate this question, as some economic geographers have argued (e.g. Massey 1997; Ray \& Sayer 1999), is by recognizing that the material / economic and the symbolic / cultural are mutually constitutive of one another; that is, "realms of life [such as the economic and the political] are mutually embedded” (Ettlinger 2003 p.149). This paper's focus on white farmers' dealings with the implementation of restitution acknowledges the mutual constitution of the economic and the cultural, of the material and the symbolic. It does so by interrogating relations between the material and symbolic 
dimensions of white farmers' dealings with land reform. The paper combines an interests in issues such as the farmers' relations to shifts in power in the agricultural sector which favour larger-scale agri-businesses (Greenberg 2003; Mather and Greenberg 2003), developments in land reform practice which favour partnerships between some of those agri-businesses and land reform beneficiaries (Shaker 2003; Fraser 2007), white farmers’ political and cultural disarticulation from the state, and the respondents' strong emotional bond to the land. I demonstrate that, for many of the white farmers in the Levubu area of northern Limpopo, the decision not to sell stemmed from their material and symbolic interests in the land. Receiving monetary payments was never likely to lead sufficient numbers to sell, a finding which calls into question the MLAR thesis and the basis for sticking with the willing-seller, willing-buyer principle.

\section{BACKGROUND}

White farmers as a group were once closely affiliated with the governing powers in South Africa. Afrikaner nationalism, which emerged in early twentieth century South Africa to challenge English-speaking whites’ dominance over the country's political economy (O’Meara 1983, 1996), constructed an imagined community (Anderson 1983) based on the definition of distinguishing cultural traits and histories. Stories of wars with Africans and the British, as well as of Afrikaners' Great Trek into the South African interior, highlighted their bravery and how they had suffered and endured injustice (Crampton 2001; Giliomee 2003). In the late 1940s, the parties of Afrikaner 
nationalism, the Afrikaner Party (AP) and Herenigde National Party (later, the Nationalist Party [NP]), stressed the position of Afrikaner farmers in this imaginary, and promised to solve a labour shortage from which white farmers were suffering. Farmers were swayed and swung their votes towards the nationalists. The HNP won "56 of the 66 rural constituencies outside Natal, and its AP Partner won a further 5” (O’Meara 1983 p. 237-38) in the 1948 national election. The nationalists “organised agricultural interests on a national scale” (ibid. p. 238) subsequent to the 1948 election. Among the many features of the post-1948 apartheid state, of particular note was the extent to which the NP rewarded and offered protection to its agricultural constituency. Agriculture enjoyed “privileged access” to state institutions and policy-making during the apartheid era (Greenberg 2003 p.48). White farmers were close allies of the apartheid state. Consequently, the commercial agriculture sector enjoyed government subsidies, protection from international competition, and labour market policies that helped secure agriculture’s access to a supply of cheap labour.

A lot, but by no means all, of this has changed with the advent of democracy in 1994 and the failure of Afrikaner nationalism to retain control over the state. White farmers are now largely disarticulated from political power. South Africa’s governing alliance’s project of ‘transformation’ is seeking - albeit with great difficulty - to alter the social landscape. Thus, in the area of agrarian relations, post-apartheid government land reform policy aims to alter the 
racially skewed distribution of land via redistribution and restitution, whilst a tenure reform programme exists to address insecure forms of tenure among historically disadvantaged groups living on white-owned farmers. Further, the old social order on white-owned farms which offered black farm workers and dwellers little if any legal protection against abuse is under attack (Human Rights Commission 2003). That having been said, it is worth noting that persisting social structures continue to confer considerable power to white farmers and their allies in some rural areas (Mayson et al. 2001; Steinberg 2002), and evidence continues to emerge of farm workers and dwellers suffering injustices at the hands of some white farmers (Wegerif et al. 2005).

Nevertheless, in the midst of the changing context in rural South Africa, there are some signs that the government's land reform policies (and possibly the fast-track [Bernstein 2002] land reform in neighbouring Zimbabwe) have led some white farmers to agree to sell land for land reform. There are also instances of white farmers taking leading roles in creating post-land reform structures such as partnerships that, they claim, are supposed to be 'win-win' solutions to the land reform challenge (Farmers Weekly August 13 2004; Fraser 2007). Yet there also is a large and vociferous group of white farmers which opposes the government's approach to land reform, if not land reform itself. White farmers associated with the Transvaal Agricultural Union (TAU), for example, are particularly vocal critics. Their stance on land reform has come to light in press releases, public statements, parliamentary hearings, and responses 
to government announcements. Drawing parallels with Zimbabwe, the TAU has expressed concern over use of expropriation orders to acquire land for land reform and even threatened violence if the government uses expropriation more widely (Mail \& Guardian, September 7 2005). TAU farmers refer to findings in alarmist books such as Du Toit's (2003) The Great South African Land Scandal to justify their oppositional stance. One outcome of the land reform process, then, and a challenge for the South African government, is a heightened sense of tensions around the issue of land ownership. It is in the context of these tensions that the research presented here was conducted.

The research seeks to fill a gap in knowledge about land reform. Various aspects of South Africa’s land reform programme have already attracted attention from geographers (Mather 2002; Ramutsindela 2002; McCusker 2004; Fraser 2007). Those contributions draw from the more extensive South African land reform literature (e.g. Cousins 2000; Lahiff 2001; Jacobs et al. 2003; Hall 2003, 2004; Walker 2003, 2005, 2006; Ntsebeza \& Hall 2006), as well as significant contributions tangentially interested in the South African case (e.g. Bernstein 2002; Borras 2003). However, although it is clear that white farmers play a critical role in affecting the pace and geography of restitution (Lahiff 2005), the precise reasons why some might refuse to sell are less well known. Indeed, neither geographers nor the broader community of land reform researchers based in South Africa have paid too much attention to the role 
played by white farmers in the unfolding land reform drama. ${ }^{\mathrm{iii}} \mathrm{I}$ now discuss how the materials presented here were collected.

\section{METHODOLOGICAL STRATEGY}

The research on the topic of why white farmers refuse to sell land for land reform took place in northern Limpopo (see Figure One) between August 2004 and May 2005. I began the research by interviewing project officers working with Nkuzi Development Association, a non-governmental organization working with numerous groups of local people engaged in benefiting from land reform, particularly via the restitution programme. The interviews with project officers as well as restitution claimants helped by Nkuzi led me to focus on a group of restitution claims on white-owned agricultural land in the Levubu area. The Levubu restitution claimants sought to restore land rights to descendants of those dispossessed in the late 1930s. They were high-profile and sensitive because the farms in Levubu were among the most valuable in South Africa and certainly among the most commercially developed in that area of northern Limpopo. The area consists of approximately 10,000 hectares of commercial horticulture farms producing mangoes, avocados, litchis, bananas, and citrus for local, national and international consumption. Perhaps as many as ten thousand people work on the farms in high season; consequently, the government had to get the transfer process right first time to ensure that restitution would not place at risk the farm workers' jobs, or the production and foreign currency earnings from Levubu. Nkuzi project officers and some of the 
restitution claimants indicated that the restitution process in Levubu was being held up by obstinate white farmers who refused to sell their land, even though the restitution claims were deemed valid by the Limpopo Land Claims Commission.

\section{[INSERT FIGUE ONE HERE.}

CAPTION: Figure One: The Levubu area of northern Limpopo Province, South

\section{Africa]}

With the intention of asking why white farmers in Levubu were refusing to sell land, I therefore proceeded to contact white farmers in Levubu, first via local leaders of the Transvaal Agricultural Union (TAU) and then via local leaders of AgriSA, another, slightly less conservative organization of commercial farmers. I first conducted interviews with farmers involved at the higher level of local decision-making within the TAU and AgriSA. The TAU official agreed to give me with a list of thirty commercial farmers based in Levubu; the AgriSA official provided a list of twenty white farmers in Levubu. I proceeded to conduct semi-structured interviews with thirty white farmers between September and December 2004. All of the respondents were men. I also carried out additional, although shorter, interviews in early 2005 to verify particular pieces of information. Almost all of the interviews were recorded on cassette tapes. The respondents' identities were protected by changing their names and precise locations. In addition to the semi-structured interviews, I organized 
three discussion groups with white farmers in December 2004. The objective was to try to identify discrepancies, parallels, and commonalities between the claims made in individual interviews and what people said whilst in a group. Two groups consisted of farmers based in Levubu, whilst the other consisted of white farmers located elsewhere in northern Limpopo. The purpose of organizing the latter group discussion was to triangulate against the other two groups with a view to identifying (in)consistencies between the situation among white farmers in Levubu and farmers elsewhere. I also conducted ten semistructured interviews with white farmers outside of Levubu with a view to determining whether there were Levubu-specific issues raised in the interviews. I acquired the latter set of names following a 'snowball' technique. Finally, I conducted repeat interviews with a leading member of one of the two Levububased farmers association and other repeat interviews with farmers during April and May 2005. These were aimed at corroborating information and clarifying various issues. Whilst I am confident in the academic quality of the materials gathered, I recognize that any process of collecting qualitative data involves subjectivities that are difficult to manage. My objective was principally to gain insights into the attitudes and perceptions of the respondents, in this case with particular regards to why they were engaging with land reform in one way or another.

\section{REFUSING TO SELL: MATERIAL AND SYMBOLIC INTERESTS}


The research in Levubu revealed that the white farmers were negotiating the restitution challenge in one of three ways. Some - 51 of the approximately 200 white farmers - had agreed to the government's offer to pay full market-related prices for their farms. Most of these 'wiling-sellers' had agreed to sell their farms with a view to remaining on the land either as partners with, mentors for, or tenants of the restitution beneficiaries. By early 2005, however, it was becoming clear that the government was leaning towards compelling the restitution beneficiaries to enter into partnerships with large-scale agribusinesses. A second, much smaller group of Levubu-based white farmers were moving to benefit from the government's shift towards partnerships. The farmers in this group owned fixed assets upstream and downstream of farming, such as a supply store in Levubu, nut-drying and juicing factories, as well as tree nurseries. They were the more successful, better capitalized farmers operating as agri-businesses, not just as individual farmers. They had decided to sell at the same time as the other willing-sellers but had split from the larger group at a subsequent stage.

A final group of farmers - the focus of this paper - was refusing to sell their farms to the government even though the government had deemed the restitution claims valid and although government officials had stated that expropriation would be used to acquire all of the claimed farms in Levubu. This latter group, which had a vocal leadership aligned with the TAU, was mostly comprised of Afrikaner farmers, most of whom operated relatively small farms 
of approximately 40 or 50 hectares. Their refusal to sell land for restitution was frustrating both the intended beneficiaries and government officials and was heightening tensions over the restitution issue. The farmers' stance was therefore an important aspect explaining the slow pace at which the government was settling the Levubu land claims. I now discuss why they were refusing to sell.

Material reasons for refusing to sell - With respect to reasons of a more material sort, the white farmers refusing to sell consistently expressed concerns about their prospects in South Africa if they sold their farms. Some suggested that a reason not to sell was because it would be difficult to find a new farm or non-agricultural venture in which to re-invest. Reflecting racially imbued conceptions of the South African government and the suspicion that land reform is a rouse to get rid of the white farmer, some claimed there was no point in selling and moving elsewhere because, "the same [land reform] laws are going to catch me there” (Personal Interview, September 2004). This was echoed by one of the younger farmers in Levubu, Johannes: “There are guys that say, 'No, just sell and go and buy a place somewhere else.' I don’t know, a few years and you find that place is claimed as well and then you must leave there as well!” (Personal Interview, November 2004). The logics underlying their stance were imbued with racial understandings in other ways. I asked all the white farmers how they believed they would fair in the non-agricultural labour market. Typical responses highlighted Black Economic Empowerment 
(BEE) policies which, according to the farmers, position them behind women and blacks at the back of the line for jobs. One farmer, Marcus, suggested that, “we wouldn’t be able to search for work anywhere else because we're not black.” (Personal Interview, October 2004). Another claimed, that "if you are a white man under 30, forget it, you'll never get a job.” (Personal Interview, October 2004). This sense of entrapment was captured by Hans: “Some say sell and go and do something else, but where do you go? I mean, we can't all do a different job somewhere else... I'd still like to stay here... It's taken me quite a few years to get the knowledge that I have now and now to start from the bottom somewhere else is going to be hard.” (Personal Interview, November 2004). The white farmers' understandings of the material interests at stake were caught up with questions of race and difference.

Insofar as selling up and moving on was understood as difficult and risky, then, many of the respondents expressed a degree of spatial entrapment: even if they wanted to sell up and leave the land, their concern was that material circumstances would prevent them from doing so. Marius even suggested the problem was about finding replicable ecological conditions unaffected by land reform: ' ...the question is what do I do with compensation? Because there's no farms where I can farm with macadamias or guavas, which is my main crops, that I can buy which is isn't under land claims' (Personal Interview, September 2004). Staying on the land, then, seemed to make sense in terms of the respondents' material interests in farming land with which they are familiar and 
growing crops they have learned to understand. As Willem pointed out, "the soft option is to leave South Africa [but] that has its own problems because I'm not going to get residence in any first-world country in the world. So where must I relocate to? You're an economic prisoner to South Africa.” (Personal Interview, September 2004).

It is helpful here to view the stance of those refusing to sell in the light of changes within the agricultural sector in South Africa (Greenberg 2003; Mather \& Greenberg 2003). Economic power in the agricultural sector is shifting to agri-businesses who, in turn, are increasingly using that power to squeeze individual farmers. These changes in South Africa reflect a broader global process in which an "emphatic neoliberal agenda for agricultural policy reform" (Potter \& Tilzey 2005 p.587) focusing on market liberalization, deregulation, and the dismantling of state support has altered the organization of agriculture throughout the world. State-provided supports to white farmers in South Africa, which were designed to keep white farmers on the land and retain their political support, have been eroded as the state has targeted more efficient producers, which has tended to be the larger export-oriented conglomerates, cooperatives or agri-businesses (Greenberg 2003). As the larger, more capitalized, exportoriented agri-businesses become increasingly dominant within the sector as a whole, small-scale individual farmers, such as many of those in northern Limpopo, face troubling times. What it means to farm is no longer as it perhaps 
once was. One of the farmers noted this changing relationship between farming and business:

The days when, 'I'm a farmer and I'm only a farmer' are long gone by. Open markets, no managing boards, banana boards are away. You're not a businessman? You don't know how to do your cash flow, your balance sheet? You won’t make it (Personal Interview, September 2004).

Relations between the large and small farmer, between the more capitalized fractions and those operating at smaller scales, are further complicated in the context of land reform: while the stance of some has been to resist land reform by wielding the principal weapon at their disposal - refusing to sell - some of the better capitalized willing-sellers in Levubu have sought ways to remain on the land as partners with restitution beneficiaries. The government has expressed interest in working with some of them, especially those with a large asset base and the ability to bring money capital to the table (Shaker 2003; Fraser 2007). But even without such options, the stance of those who have agreed to sell seems to be emblematic of changes in the structure of agriculture. Some were already moving capital into other sectors, while others mentioned options they had begun to explore:

I've been to a lot of courses and tried to look at options [outside of agriculture], but at this stage I'm thinking I'll take [my compensation] 
and move it into property and rent it out. I've started buying property in some places but not in the way that if the land claims don't go through I'm in any trouble, not at all. I'm busy with my pension on another side (Personal Interview, November 2004).

The more capitalized, larger-scale farmers, then, were not as spatially trapped or locally dependent as their counterparts who were refusing to sell. As owners of money capital they can hire people to supervise, hire advisors on what sectors to get involved in; or they may be invited to fund joint ventures. They are, therefore, not so place-bound; they can use their money capital in order, among other things, to spread risks geographically. One larger-scale farmer described exploring such an option:

[I am] not necessarily relocating money but relocating some of my own skills or some of my children's skills...That's the way to relocate. [...] We're looking all over. I'm involved in the export of citrus. I export to 18 different countries of the world and I get to go there very regularly. I’ve got my contacts. It'll actually be really simple to relocate [...] I didn’t start here with anything. I started with nothing. You can do that anywhere in the world (Personal Interview, November 2004).

Those operating at larger scales in Levubu have been more open to the opportunities land reform presents; those operating at smaller-scales and used 
to working with employees on the land, rather than with accountants and lawyers in boardrooms, have refused to sell, or have been simply unable to create a niche in the post-restitution environment. ${ }^{\text {iv }}$ Thus, there are clear material issues underlying the stance of those farmers refusing to sell for land reform in northern Limpopo: they fear leaving the area and/or agriculture; they have doubts about the labour market and concerns that their farming skills will not prove to be as transferable as some of the willing-sellers claim is in fact the case.

Symbolic reasons for refusing to sell - A second and closely interrelated set of reasons for the white farmers' refusal to sell had to do with more symbolic issues. They claim that selling land is defeatist, an affront. It is by no means a material issue alone: working the land has social meaning beyond farming; trying to hold onto it is a political action. Many of the farmers refusing to sell justified their stance through reference to their identities as Afrikaners, Boers, "people of the soil, people of the land" (Personal Interview, September 2004). In accordance with the story of Afrikaner nationalism, some explained that their forefathers:

...started 400 years ago; they trekked here, fought with malaria and the lack of infrastructure in order to build this, to leave this for us. You can still see their graves around here. We're a stubborn people, persistent, strong-willed, and independent (Personal Interview, September 2004). 
The experience of farming a particular piece of land, often with historical associations of a personal character, makes leaving the land very difficult. Many of the respondents explained how they and their forefathers transformed the area through “experience, blood and sweat, and worries” (Personal Interview, September 2004). They expressed aspects of an imaginary which stresses how they battled nature in transforming the land and in overcoming hardship. Thus, Tomas noted that:

...it was very difficult. Very poor. No water. Malaria. No infrastructure. This road here was built by my father with two oxen and a plough. So there was no infrastructure. So what happened then was these people arrived here and started farming but as poor as mice. My father was 16 years old. He didn’t even have shoes (Personal Interview, November 2004).

Farming the land is therefore important to the white farmers' sense of social significance, their sense of having achieved something. The symbolic connection to the land which farmers express is germane to their resistance. Thus, the following statement by Jan is a common refrain among those refusing to sell: “I'm bonded to this place [...] I have 100 years of roots on this place. I can see what my grandfather did, I can see what my father did...This land is our land” (Personal Interview, September 2004). Indeed, for some of the older 
farmers, the prospect of selling is a challenge to their self-esteem, ultimately their subjectivities as Afrikaners and as men. Jan claimed:

If I have to go out of here, the biggest loss will be my self-respect [...] Because you're being forced to do something you don't want to do. If I give up, what do I tell my 20 year old son? (Personal Interview, September 2004).

Given their fears about selling and their strong symbolic connection with the land, it is little wonder that some white farmers claimed they would do anything to remain in place. As Edgar, one of the older farmers noted,

Between me and you, my friend, you'll get my blood here. I'm not moving elsewhere. Where I am going to go? The street? I don't have a house in town. I have nothing else but this farm. All the money I have worked for and prayed for is in this farm. If I move out of that gate, I have the clothes on my body, and I'm not a youngster anymore. So what's it to be? I'm not going to beg for a sleeping place or for some food. Forget it. I don't say I'm going to make a war out of this, but you'll find me here. There's no other place to go. (Personal Interview, October 2004). 
Having noted the white farmers' material and symbolic interests in refusing to sell, it is worthwhile highlighting how the stance of refusing to sell was also a reflection of a particular imaginary about African farming styles; an imaginary that was used in conjunction with the 'land scandal' thesis advanced by Du Toit (2003) to further justify refusing to sell. In short, the white farmers’ story of inadequate African agriculture constructed their stance of refusing to sell into a noble endeavour; noble, that is, because they believed they were protecting South Africa by staying on the land. Of fundamental importance in this regard is the extent to which white farmers express racist, essentialist viewpoints about Africans. As Rutherford (2004) found during his research in Zimbabwe, it was common for white farmers to claim to understand the essence of their African "other". A lengthy but fairly typical example is provided in the following quote about African farming practices:

When you drive here all along the mountain, you will see the mountain there is all cut down. Scattered pieces of land. It was bush but now it's all cut down. They are planting maize there. You'll see them. Small plots of land, small little blocks, each and every one has a small block. One of my workers has a piece up there. I supplied the seed and I supplied the fertilizer to him to plant his maize. He had a good crop. He was very, very satisfied with his crop. 22 bags. Big bags. So I asked him, 'Are you selling them, the extra bags because you can only use one bag a month?' He said, 'No, this year I won't plant.' That's the mentality 
of the people. They are real subsistence farmers. (Personal Interview, December 2004; my emphasis).

Others explained that African farming practices, which they saw written on the landscape, were less commercially successful than the white farmers' either because (a) "Successful people are a threat to Africans...because in [success] they see their inability to do that” (Personal Interview, December 2004); or because (b):

One thing that is a huge problem to the black people themselves: they believe everybody is born equal. If somebody has got more than the next person, he has more because he took from someone else. And therefore they don't appreciate one person getting up and surviving or making a profit. That's not good to them (Personal Interview, November 2004).

Whereas white farmers claimed they had transformed the country and made it successful, in the process "producing enough food to feed the nation” (Personal Interview, December 2004), the African subsistence farmer's supposed lack of interest in making money would never achieve such dramatic results. Of course, by trying to identify the essence of Africans, the white farmers were attempting to define themselves in a more positive light. Such an essentialist interpretation of Africans underpins the broader argument within the predominantly white 
commercial agriculture sector - and especially within the TAU - that directly transferring land to Africans is a mistake. They also illustrate the extent to which the Afrikaner farmer's reading of South Africa’s history no longer fits with the increasingly dominant post-apartheid historical interpretation, which justifies land reform and which recognizes, rather than ignores, the multiple unequal socio-spatial structures which disadvantaged Africans and contributed to the production of particular types of agricultural landscapes. Government policy is now based on rejecting essentialist claims, achieving justice by undoing racist laws, and valuing African intellect. Such a normative view of South Africa’s past and future (however unevenly it has been pursued ${ }^{\mathrm{v}}$ ) underpins the Constitution, the land reform programme as a whole, as well as policies such as Broad-Based Black Economic Empowerment, the latter of which is aimed at eliminating racial discrimination in the economy (Iheduru 2004). Highlighting the disarticulation between white farmers' essentialist viewpoints and the orientation of government policy, government officials in Limpopo noted that, whilst they might seek out white farmers to become partners with land reform beneficiaries, those farmers must reject racism. A high-ranking government official commented as follows on what sort of attitude white farmers need if they are to become partners with land reform beneficiaries: “In terms of attitude, he should have the right attitude. You're not going to go into a partnership with somebody who still has the master-servant mentality, that, 'I’m white, I'm superior, you're black, you are only a worker.' Because all of a sudden we have become equals...we need to respect each 
other” (Personal Interview with Official from Limpopo Land Claims

Commission, November 2004). Equally as much as officials compel white farmers to abandon their racist understandings of life in South Africa, policies and programmes such as land reform seek to create structures which move the country beyond them. Land reform is, after all, and as two of the government's leading bureaucrats have noted, intended to transform the agrarian structure and create a new dispensation in which racist white farmers have no role to play (Mbongwa \& Thomas 2005). The white farmers' affiliations with the old order and expressions which demonstrate these affiliations are therefore increasingly redundant as the terrain within which they operate changes.

\section{CONCLUSION}

To summarize the materials presented, the white farmers refusing to sell land for restitution in Levubu identified a variety of material and symbolic reasons for their stance of refusing to sell land. They expressed fears about the true intentions of the government. Changes in the structure of the agricultural sector had already left them vulnerable to competition from larger agri-businesses. The material stakes were high; selling and establishing a new economic niche was risky. But the farmers also expressed more symbolic interests. There were attachments to the land; senses of belonging closely bound up with their identities as farmers, as Boers. Selling would be an affront to some and a defeat for others. Staying on the land, moreover, was for some of the white farmers, including those at high levels of local decision-making in the Levubu-based 
farming associations, a noble endeavour because they believed that South African agriculture would continue to survive if - and only if - they stayed on the land. In their view, Africans were inherently incapable of meeting the country's economic demands. The farmers repeated claims advanced nationally by the TAU that land reform approaches that fail to involve white farmers will lead the country towards disaster. Thus, the decision to stay on the land was explained by some as a matter of principle. Others, meanwhile, explained it as a lack of choice; that is, the farmers expressed a strong sense of spatial entrapment, which compelled them to stay on the land. In short, their actions stemmed from material and symbolic reasons. I should like to argue that these material and symbolic reasons - the economic and the cultural - were mutually constitutive of one another.

I would like to end the paper by suggesting what might be the significance of these materials for land reform policy. My research in Levubu illustrates one critical, yet largely over-looked aspect of the South African approach to delivering land reform: the logic guiding modes of land acquisition in South Africa. The South African government's decision to acquire land via the 'willing-seller, willing-buyer' principle has attracted a lot of attention among observers of land reform in South Africa. Adherence to the principle is "one of the defining characteristics of the programme” (Lahiff 2005 p.1). Much of the attention has focused on whether the government should have adopted the principle, and whether it should continue to stick to it (e.g. see Eveleth \& 
Mngxitama 2003; Hall \& Ntsebeza 2006 pp. 17-20). For understandable reasons, the interests of the intended beneficiaries of land reform have been at the core of the debate: the overriding question is whether the willing-seller, willing-buyer principle speeds up the delivery of land. I want to highlight another dimension of the issue. Insufficient numbers of landowners agreeing to sell their land demonstrates that offering them full (or, even above) marketrelated prices will not guarantee that they will sell. Yet the logic of the willingseller, willing-buyer principle suggests they will. The logic is based on the assumption in the MLAR thesis that landowners are motivated primarily by material interests. This paper suggests otherwise; landowners are not motivated by material interests alone. The government's approach to acquiring land, therefore, should be called into question. Its logic is unsuited to the real world conditions in which material interests cannot be assumed to trump all others. For some to the South African government's left, such an argument will be succour to the position in favour of moving towards widespread expropriations of white-owned land. It was not my intention to lend support to that line of argument; however, it is difficult to imagine how the government will be able to complete restitution without taking such measures. 


\section{REFERENCES:}

ANDERSON B (1983), Imagined Communities. Imagined communities:

Reflections on the origin and spread of nationalism. London: Verso.

BEINART, W. (2001), Twentieth-century South Africa. New York: Oxford University Press.

BERNSTEIN, H. (2002), Land reform: taking a long(er) view. Journal of Agrarian Change 2, pp. 433-463.

BORRAS, S. JR. (2003), Questioning the Pro-Market Critique of State-Led Agrarian Reform. European Journal of Development Research 15, pp. 105-128.

BORRAS, S. JR. (2005), Can redistributive reform be achieved via marketbased voluntary land transfer schemes? Evidence and lessons from the Philippines. The Journal of Development Studies 41, pp. 90-134.

COUSINS, B. ed. (2000), At the crossroads : land and agrarian reform in South Africa into the 21st century. Bellville, South Africa: Programme for Land and Agrarian Studies, School of Government, University of the Western Cape.

CRAMPTON, A. (2001), The Voortrekker Monument, the birth of apartheid, and beyond. Political Geography 20, pp. 221-246. 
DEININGER, K. \& H. BINSWANGER (1999), The evolution of the World Bank's land policy: principles, experience, and future challenges. The World Bank Research Observer 14, pp. 247-276.

DU TOIT, P. (2004), The great South African land scandal. Centurion: Legacy Publications.

ETTLINGER, N. (2003), Cultural economic geography and a relational and microspace approach to trusts, rationalities, networks, and change in collaborative workplaces. Journal of Economic Geography 3, pp. 145-171.

EVELETH, A. \& A. MNGXITAMA (2003), The Struggles of South Africa's Landless. Development Update 4, pp. 149-166.

FARMERS WEEKLY (2004), Land reform: Meet the good guys. August $13^{\text {th }}$.

FRASER, A. (2007), Hybridity emergent: Geo-history, learning, and land restitution in South Africa. Geoforum 38, pp. 299-311

GHIMIRE, K. (2001) Land Reform at the end of the twentieth century: an overview of issues, actors and processes. In: GHIMIRE, K. ed., Land reform and peasants livelihoods: the social dynamics of rural poverty and agrarian 
reforms in developing countries, pp. 1-22. London: Intermediate Technology Development Group Publishing.

GILIOMEE, H. (2003), The Afrikaners: Biography of a People. Charlottesville: University of Virginia Press.

GREENBERG S (2003), Land reform and transition in South Africa. Transformation. 52, pp. 42-67.

HALL, R. (2003), Rural restitution: Evaluating land and agrarian reform in South Africa. Cape Town: Programme for Land and Agrarian Studies.

HALL, R. (2004), Land and agrarian reform in South Africa: A status report. Cape Town: Programme for Land and Agrarian Studies.

HUMAN RIGHTS COMMISSION (2003), Final report on the inquiry into human rights violations in farming communities. South Africa Human Rights Commission: Johannesburg.

IHEDURU, O.C. (2004), Black economic power and nation-building in postapartheid South Africa. Journal of Modern African Studies 42, pp. 1-30. 
JACOBS, P., E. LAHIFF, \& R. HALL (2003), Land redistribution. Cape

Town: Programme for Land and Agrarian Studies.

JEEVES, A. \& J. CRUSH (1997), White Farms, Black Labor: The State and Agrarian Change in Southern Africa, 1910-50. Portsmouth NH, Pietermaritzburg and Oxford: Heinemann, University of Natal Press and James Currey.

LAHIFF, E. (2001), Land reform in South Africa: Is it meeting the challenge? Cape Town: Programme for Land and Agrarian Studies.

LAHIFF, E. (2005), From 'willing seller, willing buyer' to a people-driven land reform. Cape Town: Programme for Land and Agrarian Studies.

LEVIN, R. \& D. WEINER eds. (1997), "No More Tears...": Struggles for Land in Mpumalanga, South Africa. Eritrea: Africa World Press.

MAIL \& GUARDIAN (2005), Farmers threaten armed struggle. September 7th. Available: http://www.mg.co.za/articlePage.aspx?articleid=250273\&area=/breaking_news /breaking_news_national/ Accessed: November $4^{\text {th }} 2005$. 
MAMDANI, M. (1996), Citizen and subject : contemporary Africa and the legacy of late colonialism. Princeton, N.J.: Princeton University Press.

MASSEY, D. (1997), Economic/non-economic. In: LEE, R \& J. WILLS eds., Geographies of economies, pp. 27-36. Arnold: London.

MATHER C. \& S. GREENBERG (2003), 'Market liberalisation in postapartheid South Africa: The restructuring of citrus exports after 'deregulation'. Journal of Southern African Studies 29, pp. 393-412.

MATHER, C. (2002), The changing face of land reform in post-apartheid South Africa. Geography. 87, pp. 345-354.

MATHIS, S. M. (2007), The Politics of Land Reform: Tenure and Political Authority in Rural Kwazulu-Natal. Journal of Agrarian Change 7, pp. 99-120.

MAYSON, D., R. JACOBS \& A. ISAACS (2001), Racism in Rural Areas. Is Agrarian Reform the solution? Cape Town: Surplus People Project.

MBONGWA, M. \& G. THOMAS (2005), Response to articles and interview by Anne Bernstein emanating from "land reform in South Africa: a $21^{\text {st }}$ Century Perspective'. <http://www.sarpn.org.za/documents/d0001268/P1505-

DLA_response_June2005.pdf> Accessed: July 22nd 2005. 
MCCUSKER, B. (2004), Land use and cover change as an indicator of transformation on recently redistributed farms in Limpopo Province, South Africa. Human Ecology 32, pp. 49-75.

NTSEBEZA, L (2006), Land redistribution in South Africa: The property clause revisited. In: NTSEBEZA, L \& R. HALL, The Land Question in South Africa: The Challenge of Transformation and Redistribution, pp. 107-131. Cape Town: HSRC Press.

NTSEBEZA, L. \& R. HALL (2006) The Land Question in South Africa: The Challenge of Transformation and Redistribution. Cape Town: HSRC Press.

O’MEARA, D. (1983), Volkskapitalisme: Class, capital, and ideology in the development of Afrikaner nationalism, 1934-1948. New York: Cambridge University Press.

O’MEARA, D. (1996), Forty Lost Years: The Apartheid State and the Politics of the National Party 1948-1994. Athens, Ohio: Ohio University Press.

PLATZKY, L. \& C. WALKER (1985), The Surplus People. Forced Removals in South Africa. Johannesburg: Ravan Press. 
POTTER, C. \& M. TILZEY (2005), Agricultural policy discourses in the European post-Fordist transition: neoliberalism, neomercantilism and multifunctionality. Progress in Human Geography 29, pp. 581-600.

RANGAN, H. \& M. GILMARTIN (2002), Gender, traditional authority and the politics of rural reform in South Africa. Development and Change 33, pp. 633658.

RAY. L. \& A. SAYER (1999), Culture and economy after the cultural turn. London: Sage.

RAMUTSINDELA, M. (2002), The perfect way to ending a painful past? Makuleke land deal in South Africa, Geoforum 33, pp. 15-24.

RUTHERFORD, B. (2004), "Settlers" and Zimbabwe: Politics, memory, and the anthropology of commercial farms during a time of crisis. Identities-Global studies in culture and power 11, pp. 543-562.

SHAKER, M. (2003), Restructuring of state assets in Limpopo, Service Delivery Review 2, pp. 73-77.

STEINBERG, J. (2002), Midlands. Johannesburg: Jonathan Bull. 
UMHLABA WETHU (2005), A quarterly bulletin tracking land reform in South Africa. Cape Town: Programme for Land and Agrarian Studies.

November.

WALKER, C. (2003) Piety in the sky? Gender policy and land reform in South Africa, Journal of Agrarian Change 3, pp. 113-148.

WALKER, C. (2005), The limits to land reform: Rethinking 'the land question', Journal of Southern African Studies 31, pp. 805-824.

WALKER, C. (2006) Redistributive land reform: For what and for whom? In: NTSEBEZA, L \& R. HALL eds. The Land Question in South Africa: The Challenge of Transformation and Redistribution, pp. 132-152. Cape Town: HSRC Press.

WEGERIF, M., B. RUSSELL \& I. GRUNDLING (2005) Still Searching for Security. The Reality of Farm Dweller Evictions in South Africa. Polokwane North: Nkuzi Development Association.

\section{Acknowledgements}

I must acknowledge the generous funding support for the research provided by the Mershon Center and Kirwan Institute at The Ohio State University. In Limpopo province, project officers at Nkuzi Development Association and 
white farmers in the local Transvaal Agricultural Union and AgriSA went out of their way to help. Kevin Cox provided excellent advice and support throughout the research process. Any errors are my responsibility.

\section{ENDNOTES}

At least 1.1 million African farm workers, tenants and 'squatters' were cleared off of white-owned land (Mamdani 1996 p.31) and around 800,000 Africans were relocated in urban areas under the terms of the Group Areas Act (Mamdani 1996 p.35). The African population living in the homelands "grew from 4.2 million in 1960 (39\% of all Africans) to over 11 million in 1980 (52.7\%)” (Beinart 2001 p.212).

ii Likewise, the hunger for land among the landless is not simply an economic matter. More cultural or symbolic factors are germane to many restitution claims, particularly those in which claims are closely intertwined with the desire on the part of the claimants to re-connect with ancestral graves. As Mathis (2007) has demonstrated, moreover, understanding claims for land cannot be divorced from issues of extra-economic power.

iii White farmers have certainly not been ignored in the non-geographical literature on South Africa. Noteworthy contributions include an edited collection on power relations on white farms (Jeeves \& Crush 1997), an 
account of post-apartheid struggles involving white farmers in particular regions of the country (Steinberg 2002), and the dynamics of agricultural restructuring (Greenberg 2003).

iv Arguably, the resistance of the smaller-scale farmers was partly a product of their exclusion from the settlement process. It was highly unlikely they would have had requisite financial or social capital to bring to the table even if they had wanted to become partners; if the government went looking for potential partners, the smaller-scale farmers would have struggled to compete.

v For example, as Rangan \& Gilmartin (2002) note with respect to gender empowerment, government practice still deviates from the country's Constitutional objectives. 